\title{
10. Unilateral conduct by non-dominant firms: a comparative reappraisal
}

\section{Florian Wagner-von Papp}

\subsection{INTRODUCTION}

Ten years ago, in 2008, an International Competition Network (ICN) Task Force Report looked into the rules on superior bargaining positions in several jurisdictions worldwide. ${ }^{1}$ It found that a few jurisdictions had specific rules on superior bargaining positions, or functionally equivalent competition law or non-competition law rules, but that other jurisdictions, such as the United States, did not have any functionally equivalent rules for unilateral conduct of non-dominant firms.

This chapter addresses two questions, one of a descriptive-comparative nature and one of a normative nature.

As a matter of descriptive-comparative law, part 10.2 revisits the question how Japan, Germany and the United States approach unilateral conduct of firms below the threshold of dominance on the relevant market from a functional-comparative perspective. My conclusion in the descriptive-comparative part of the chapter is that all three jurisdictions, including the US, apply rules to unilateral conduct of nondominant firms, often in similar situations.

The second, normative question is whether unilateral conduct by non-dominant firms raises competition concerns and requires intervention by competition law. This question is addressed in part 10.3 of this chapter. Supermarket chains have historically been one of the primary targets of these rules, ${ }^{2}$ and increasing

\footnotetext{
1 ICN Task Force for Abuse of Superior Bargaining Position, Report on Abuse of Superior Bargaining Position, 7th Annual Conference, Kyoto (14-16 April 2008) available at <http://www.internationalcompetitionnetwork.org/uploads/library/doc386.pdf> (last accessed 20 August 2018).

2 For the position of chain stores as the 'public enemy' in the US during the Great Depression, see P Areeda and H Hovenkamp, Antitrust Law: An Analysis of Antitrust Principles and Their Application (3rd edn, New York, Aspen 2006-13) § 2302.
} 
concentration in this sector has renewed the calls for protection of vulnerable suppliers and corresponding enforcement action, especially in the food sector. ${ }^{3}$

My conclusion in the normative part of the chapter is that unilateral conduct below the threshold of dominance on the relevant market should not be subject to competition law scrutiny. ${ }^{4}$ From a conceptual standpoint, there will rarely be a credible theory of competitive harm. There may be isolated cases in which a credible theory of harm can be advanced. However, the sum of the administrative costs and the costs of type I errors (false positives) that result from the application of vague competition law rules, such as rules on superior bargaining positions, far outweigh the costs from type II errors (false negatives) which result where competition law practices abstinence in the few problematic cases. Also, some of the more egregious

3 See, for example, European Commission, 'Green Paper on Unfair Trading Practices in the Business-to-Business Food and Non-Food Supply Chain in Europe', COM(2013) 37 of 31 January 2013; European Commission, The Economic Impact of Modern Retail on Choice and Innovation in the EU Food Sector: Final Report (September 2014), available at <http://ec.europa.eu/competition/publications/KD0214955ENN.pdf> (last accessed 20 August 2018); Bundeskartellamt (Federal Cartel Office), Sektoruntersuchung Lebensmitteleinzelhandel Abschlussbericht (30 September 2014), available at <http://www.bundeskartellamt.de/Sektoruntersuchung_LEH.pdf?_blob=publicationFile\&v=7> (last accessed 20 August 2018); Bundeskartellamt - EDEKA [3 July 2014] B2-58/09, partially annulled by OLG Düsseldorf [18 November 2015] VI-Kart 6/14 (V), but largely reinstated by BGH [23 January 2018], KVR 3/17, ECLI:DE:BGH:2018:230118BKVR3.17.0 - Hochzeitsrabatt; see also Bundeskartellamt - EDEKA/Tengelmann [31 March 2015] B2-96/14; Organisation for Economic Cooperation and Development (OECD), Policy Roundtable Buying Power of Multiproduct Retailers, DAFFE/CLP(99)21 (1998), available at <http://www.oecd.org/daf/competition/abuse/2379299.pdf> (last accessed 20 August 2018); OECD, Policy Roundtable Monopsony and Buyer Power, DAF/COMP(2008)38 (2008), available at <http://www.oecd.org/daf/competition/44445750.pdf> (last accessed 20 August 2018); P Chauve and A Renckens, 'The European Food Sector: Are Large Retailers a Competition Problem?' (2015) 6 Journal of European Competition Law and Practice (JECLAP) 513. For a comparative analysis including Japan, see K Fuchikawa's contribution to this volume.

4 See the proviso below for unilateral conduct that aims at collusive conduct, such as invitations to collude; here, I am in favour of continued, in some cases even enhanced, scrutiny. 
cases not caught by competition rules may still be scrutinized from the perspective of contract law. ${ }^{5}$

This does not necessarily mean that all cases in which rules such as those on superior bargaining position are currently applied should be given a clean bill of health. These rules are often employed in cases in which the firm in the 'superior' bargaining position is actually dominant on a properly defined relevant market. In some cases in which rules on superior bargaining positions are enforced, the question of dominance is simply not addressed because it is easier for the competition authority or plaintiff to rely on the lower threshold of a superior bargaining position.

Moreover, as Professor Shiraishi Tadashi has pointed out, in some of the cases addressed under the provisions on superior bargaining positions, the circumstances that prevent the dependent parties from switching to another partner may be reasons to define the relevant market more narrowly on the basis of a 'lock in' rationale. ${ }^{6}$ This chapter accepts Professor Shiraishi's 'baseline' that the factors used to justify the superior bargaining position should give pause for thought, and in some cases may justify a narrower market definition than a first glance might suggest. Nevertheless, one must not jump too quickly to the conclusion that a relevant 'lock in' exists. Otherwise, one would risk falling into what is known as the 'toothless fallacy': defining a market by the infra-marginal consumer instead of the marginal consumer.

The normatively desirable approach proposed in this chapter is therefore

(1) to require the addressee to be dominant on the relevant market before its unilateral conduct is scrutinized under competition law,

(2) to allow for the possibility that the relevant market may be narrower than it would at first appear where the 'dependent' undertaking is 'locked in', while

5 This reduces the costs from false negatives even further, but, necessarily, slightly raises the costs from false positives again. However, because of the different consequences of contract and competition law, the costs from false positives under contract law is arguably not high.

6 T Shiraishi, 'A Baseline for Analyzing Exploitative Abuse of a Dominant/Superior Position' (2013) 5 UT Soft Law Review 1, 6, available at <http://ssrn.com/abstract=2246558> (last accessed 20 August 2018). 
(3) paying proper attention to the principles used in market definition, such as the importance of focussing on marginal consumers rather than those consumers whose elasticity of demand is lowest, or the necessity to consider both demand-side and supply-side substitutability.

Under such an approach, a subset of those cases currently scrutinized under the provisions on superior bargaining positions will still be caught by competition law, but the analysis will become more rigorous, because it requires a convincing theory of harm.

A final consideration is that abolishing rules on superior bargaining positions could increase the costs from false negatives: where the firm in question is actually dominant, there may be competitive harm from its abusive conduct, but it may escape competition law scrutiny where the competition authority or the plaintiffs lack the necessary information to prove dominance. To the extent this is seen as creating unacceptable costs of false negatives, jurisdictions with rules on superior bargaining positions should consider at least downgrading the prohibition of abuses of superior bargaining positions to mere presumptions of dominance. This would leave the costs of false negatives similar to the current level, but would substantially reduce the costs of false positives.

\subsection{IS UNILATERAL CONDUCT OF NON-DOMINANT FIRMS SUBJECT TO} COMPETITION LAW? A LEGAL COMPARISON

\subsubsection{Background and Scope of the Enquiry}

This section outlines the rules on unilateral conduct rules for non-dominant firms, such as the rules on superior bargaining positions or its flipside, economic dependency, in Japan and Germany, and functionally equivalent rules in the United States. As so often in comparative law, the national terminology and definitions differ between jurisdictions, and one has to take care to capture all rules that address the same 'real life problem', irrespective of whether they are called 'prohibitions of abuses of superior bargaining positions'. 
Before identifying the real world issue that is raised by the various rules on superior bargaining or economic dependency provisions, it should be noted that in many respects the jurisdictions surveyed here share the fundamental approach to competition law. There is a consensus that a firm in a dominant position, that is, a firm with a sufficient degree of market power, is subject to certain legal constraints on its unilateral conduct. The general rule is, however, that unilateral conduct by nondominant firms is unproblematic from a competition policy perspective.

The reason for this general rule is that vigorous competition is more likely to result when firms know that they are acting in a safe harbour provided only (1) they do not enter into restrictive (horizontal or vertical) agreements, and (2) they are not in a dominant position. Within this safe harbour for non-dominant firms, they are completely free as to their choice of parameters for unilateral conduct, such as choosing or rejecting trading partners, negotiating for different conditions with each of the trading partners, setting their own prices as high or low as they wish, and so on. This ensures that there is a wide variability of competitive actions in the marketplace, there is a wide range of choices for consumers, and the selection process of competition will determine which approach serves consumer demand best and most efficiently.

In addition to these positive effects of a safe harbour, it is unlikely that any competitive harm could result even if one non-dominant firm tried to act anticompetitively: in the absence of dominance or restrictive agreements, exclusionary or exploitative effects are improbable. While 'consumer harm' is not completely impossible - for example: a non-dominant merchant charges more than other merchants in a competitive market, and some consumers do not immediately realize the price discrepancy - this will be a transitory problem, one that is not to be addressed by competition (antitrust) law because it derives from information asymmetry rather than market power, and one that will be fixed by the self-healing propensity of competitive markets. The costs of a false negative are not zero, but so low that any intervention to fix the problem would result in higher costs by stifling free competition. Conversely, a non-dominant merchant who attempts price predation may divert some sales from its competitors, but would transfer money to consumers 
and would - absent a dangerous probability of monopolizing the $\operatorname{market}^{7}-$ do no lasting harm to competition because predation would not be sustainable.

The 'real life issues' in the legal comparison, then, are scenarios in which jurisdictions depart from this general rule of a safe harbour for unilateral conduct of non-dominant firms.

Accordingly, for the purposes of the comparison, this chapter will consider 'rules on unilateral conduct of non-dominant firms' to comprise all rules on unilateral conduct that apply to firms irrespective of whether they have a dominant position in the relevant market. This may mean that the rules require some heightened degree of market or bargaining power, or that they do not require any degree of market or bargaining power. For the purpose of this enquiry, I exclude rules on unilateral conduct that are meant to prevent collusion between competitors in its incipiency, such as prohibitions of invitations to collude or calls for a collective boycott. Even though technically they are rules on unilateral conduct, they ultimately seek to prevent horizontal agreements.

The scope of unilateral conduct to be examined is more difficult to define in the abstract.

On the one hand, there are certain types of prohibitions on unilateral conduct that have no, or very little, relation to competition policy concerns. For example, nondominant firms are prohibited from selling poisonous food, and few would take issue with taking such conduct out of the 'safe harbour'.

In contrast, prohibitions related to 'unfair trade practices' are often very closely related to competition policy concerns, because unilateral conduct by non-dominant firms is prohibited precisely because of its effects on competitive relationships. In

$7 \quad$ To the extent that a legal system does not prohibit the monopolization (as does section 2 Sherman Act) but only the abuse of an existing dominant position (as do Article 102 of the Treaty on the Functioning of the European Union (TFEU) and $\S 19$ of the German Act against Restraints of Competition (ARC)) there could be a risk of false negatives. However, given that a dominant position may start in the vicinity of a 40 per cent market share (under $\S 18 \mathrm{ARC}$, dominance is presumed from 40 per cent, even though it is a weak presumption), this source of false negatives is, however, more a theoretical than a practical issue. 
some cases, the different thrust of 'unfair trade practices' can be used to separate them out. Many of these unfair trade practices are aimed at preventing deception that would interfere with the competitive process by preventing consumers to act in accordance with their preference ordering. The theory of harm underlying these rules is not that the unilateral conduct distorts competition because of market power of any kind, but because of information asymmetry.

Other unfair trade practices, however, are less clearly aimed at combatting information asymmetry. One set of the prohibitions that will be examined below, namely rules against selling below a certain measure of cost, are often addressed by rules on dominant undertakings (predatory pricing in the US, the EU, Germany, France and Japan), 'superior bargaining power/economic dependency' (France, Germany and Japan) and as an unfair trade practice (state 'sales below cost' laws in the US, Germany, France and Japan). As will be discussed below, the stated rationale of these and similar rules fluctuates between 'market power light' and 'deception'.

\subsubsection{Overview of the Legal Formants on 'Unilateral Conduct of Non-Dominant Firms' in Japan and Germany}

\subsubsection{Japan}

Today, ${ }^{8}$ the main rules on superior bargaining positions in Japan are found in Articles 19, 2(9) of the Antimonopoly Act (AMA). ${ }^{9}$ Article 19 of the AMA prohibits 'unfair

\footnotetext{
8 The applicable rules have slightly changed when the Antimonopoly Act (AMA) was amended in 2009 (Act No 51 of 2009). Before this amendment, the rules on superior bargaining positions were to be found mainly in the General Designation of Unfair Trade Practices of 1982, paragraph 14 (see, eg, A Inoue, Japanese Antitrust Law Manual: Law, Cases, Interpretation of Japanese Antimonopoly Act (Alphen aan den Rijn, Kluwer Law International 2007) 77-9; ICN Task Force for Abuse of Superior Bargaining Position, Report on Abuse of Superior Bargaining Position, 7th Annual Conference, Kyoto (April 14-16, 2008), available at <http://www.internationalcompetitionnetwork.org/uploads/library/doc386.pdf> (last accessed 20 August 2018), at 7). Three of the alternatives mentioned in the former paragraph 14 of the General Designation have now been moved to Article 2(9)(v) AMA (see text following this footnote), the remaining designation has moved to No 13 of the General Designation of Unfair Trade Practices of
} 
trade practices'. Article 2(9)(v) of the AMA includes in the definition of prohibited 'unfair trade practices': 10

"(v) Engaging in any act specified in one of the following by making use of one's superior bargaining position over the counterparty unjustly, in light of normal business practices:

(a) Causing said counterparty in continuous transactions (including a party with whom one newly intends to engage in continuous transactions; the same applies in (b) below) to purchase goods or services other than those to which said transactions pertain;

(b) Causing said counterparty in continuous transactions to provide money, services or other economic benefits;

(c) Refusing to receive goods in transactions with said counterparty, causing said counterparty to take back such goods after receiving them from said counterparty, delaying payment to said counterparty or reducing the amount of payment, or otherwise establishing or changing trade terms or executing transactions in a way disadvantageous to said counterparty.

The Japan Fair Trade Commission's (JFTC) 'Guidelines Concerning Abuse of Superior Bargaining Position under the Antimonopoly Act' of 30 November 2010

1982, Public Notice No. 15 of 18 June 1982, as revised with effect from 4 January 2010 (in the following: the 'General Designation').

$9 \quad$ For excellent overviews over law and practice in Japan, see, eg, M Wakui and TK Cheng, 'Regulating Abuse of Superior Bargaining Position under the Japanese Competition Law: An Anomaly or a Necessity?' (2015) 3 Journal of Antitrust Enforcement 302; S Takizawa and K Arai, 'Abuse of Superior Bargaining Position: The Japanese Experience' (2014) 5 Journal of European Competition Law and Practice 557; E Kameoka, Competition Law and Policy in Japan and the EU (Cheltenham, UK and Northampton, MA, USA, Edward Elgar, 2014) 86-95; H Oda, Japanese Law (3rd edn, Oxford, OUP 2009) 344 et seq, 350-51.

10 Antimonopoly Act (AMA), English translation available at <http://www.jftc.go.jp/en/legislation_gls/amended_ama09/amended_ama15_01.html> (last accessed 20 August 2018). 
explain and illustrate the enumerated forms of abuse in Article 2(9)(v) AMA, both with actual and hypothetical ('supposed') examples. ${ }^{11}$

These Guidelines also explain when a 'superior bargaining position' exists. It is not necessary for the party to be dominant on the relevant market; it is enough that the party has a 'superior bargaining position' relative to the other (dependent) party. ${ }^{12}$ Such a superior bargaining position exists where the second, allegedly dependent, party would have to accede even to 'substantially disadvantageous' requests by the first party, because it would otherwise have 'difficulty in continuing the transaction with [the first party] and thereby [the second party's] business management would be substantially impeded'. ${ }^{13}$ Whether or not this is the case is determined by a comprehensive analysis of (1) the degree of the second party's dependence on the first party as measured by the proportion of sales with the first party compared to the total amount of the second party's sales; (2) the position of the first party in the relevant market, as determined by the market share and ranking; (3) the possibility of the second party switching its demand or supply from the first party to another partner, in particular considering transaction-specific investments made by the second party; and (4) other factors, such as the absolute amount of transactions between the first and second party, the growth potential of the first party, the differential in the business

11 In the following: JFTC, 'Guidelines on Superior Bargaining Position 2010'; a tentative English translation is available at <https://www.jftc.go.jp/en/legislation_gls/imonopoly_guidelines_files/101130GL.pdf> (last accessed 20 August 2018). In the version of 30 March 2015, the JFTC 'Guidelines Concerning Distribution Systems and Business Practices under the Antimonopoly Act' contained an additional very brief overview of the rules on superior bargaining position in Part II Chapter 5. The newer version of these Guidelines (last revised 16 June 2017) only refer to the Guidelines on Superior Bargaining Position 2010, see Part I, 1 (2) (tentative English translation available at <https://www.jftc.go.jp/en/legislation_gls/imonopoly_guidelines_files/DistributionSystemsAndBusines sPractices.pdf > (last accessed 20 August 2018).

12 Guidelines on Superior Bargaining Position 2010, n 11, at 5. But see the criticism of this approach by $\mathrm{T}$ Shiraishi, 'A Baseline for Analyzing Exploitative Abuse of a Dominant/Superior Position' (2013) 5 UT Soft Law Review 1, 3-6, available at <http://ssrn.com/abstract=2246558> (last accessed 20 August 2018), and below Part 10.3.

13 Guidelines on Superior Bargaining Position 2010, n 11, at 5. 
size between the first and second party, or the reputational effects for the second party by being associated with the first party's brand. ${ }^{14}$

The Guidelines emphasize that a superior bargaining position may not only exist between a large and small or medium-sized enterprises (SMEs), but also between two large enterprises or two SMEs. ${ }^{15}$

With regard to the 'abuse' of a superior bargaining position, the Guidelines mostly discuss unilateral ex post opportunism contrary to an existing contract between the parties to which the other party agrees out of necessity - in other words: where, without the coerced modification of contractual obligations there would be a breach of contract. In many of the examples in the Guidelines (and in the JFTC's practice), the abusive conduct consists in 'forcing' the contract partner to purchase unrelated and/or unwanted items, in refusing without good cause acceptance of goods or services that are tendered in accordance with the contract, or in refusing payment despite performance.

However, it is apparently not necessary that a contract is already in place. Article $2(9)(v)(c)$ AMA covers both 'changing' and 'establishing' terms, and under the heading 'unilateral decision on a consideration for transactions', the Guidelines do not seem to require a pre-existing contract between the parties. ${ }^{16}$ According to Shiraishi Tadashi, there is a consensus among

14 Guidelines on Superior Bargaining Position 2010, n 11, at 5-6, with examples from case law at 7-9.

15 Guidelines on Superior Bargaining Position 2010, n 11, at 5. Given that the differential in size is a (though not necessarily the decisive) factor in finding a superior bargaining position, it may on the margin be more likely that a large firm will be found to be in such a position vis-à-vis an SME.

16 Guidelines on Superior Bargaining Position 2010, n 11, at 28; see also the hypotheticals [4][6], ibid, at 30, although the facts are not sufficiently detailed to give an unambiguous answer. If the provisions only applied to renegotiations during the duration of an existing contract, there would be an obvious incentive for parties with superior bargaining powers to negotiate short-term contracts. For examples of ex post unilateral price reductions contrary to an existing contract, see, eg, the SanyoMarunaka and Toys ' $R$ 'Us cases, discussed in S Takizawa and K Arai, 'Abuse of Superior Bargaining Position: The Japanese Experience' (2014) 5 Journal of European Competition Law and Practice 557, 558-9 and passim; see also the excellent analysis in M Wakui and TK Cheng, 'Regulating Abuse of Superior Bargaining Position under the Japanese Competition Law: An Anomaly or a Necessity?' (2015) 3 Journal of Antitrust Enforcement 302. 
practitioners and scholars [...] that the majority of cases fall into one of two categories of abuse [. . .]. The first category is, to be sure, a contractual breach or 'unforeseeable disadvantage'. [ . . .] The second category is 'excessive disadvantage' for future trade. [The Sumitomo Mitsui Banking Corporation (SMBC) case] is an example of excessive disadvantage because SMBC made the unwanted tie a condition of receiving a new loan. ${ }^{17}$

Accordingly, it appears that even when there is no existing contract between the parties, there can be a 'superior bargaining position', and an abuse can consist of demanding excessive consideration not only in the modification of an existing, but even in the negotiation of a new contract. Whether the consideration is excessive is:

\begin{abstract}
determined after comprehensively considering the method for deciding on the consideration, such as whether or not the entrepreneur conducted sufficient discussions with the transacting party when deciding on the consideration, as well as whether or not the consideration is discriminatory in comparison to the consideration for other transacting parties, whether or not the consideration is lower than the transacting party's purchase price, the difference between the normal purchase price or selling price, and the supply-and-demand relationship of the goods or services subject to the transactions. $^{18}$
\end{abstract}

There is no abuse where the request is motivated by a meeting-competition constellation or where the consideration is a 'just reflection on the difference in the trade terms'. ${ }^{19}$ Because of the difficulty that is inherent in the inquiry whether the

17 T Shiraishi, 'A Baseline for Analyzing Exploitative Abuse of a Dominant/Superior Position' (2013) 5 UT Soft Law Review 1, 6, available at <http://ssrn.com/abstract=2246558> (last accessed 20 August 2018) (emphasis added). Similarly, S Takizawa and K Arai, 'Abuse of Superior Bargaining Position: The Japanese Experience' (2014) 5 Journal of European Competition Law and Practice 557, 561 (also using the dichotomy unforeseen disadvantage/foreseeable 'remarkable disadvantages') and M Wakui and TK Cheng, 'Regulating Abuse of Superior Bargaining Position under the Japanese Competition Law: An Anomaly or a Necessity?' (2015) 3 Journal of Antitrust Enforcement 302.

$18 \quad$ Guidelines on Superior Bargaining Position 2010, n 11, at 29.

19 Guidelines on Superior Bargaining Position 2010, n 11, at 29. 
consideration is substantively 'adequate', Japanese authorities prefer to focus on the procedural element whether there were 'sufficient discussions' between the parties. ${ }^{20}$ In addition to the conduct enumerated in Article 2(9)(v) AMA as abuses of a superior bargaining position, the JFTC may designate further conduct as 'unfair trade practices' under Article 2(9)(vi) AMA, namely: ${ }^{21}$

(vi) Any act falling under any of the following items which tends to impede fair competition [...] other than the acts listed in the preceding items:

(a) Unjustly treating other enterprises in a discriminatory manner;

(b) Engaging in transactions at an unjust price;

(c) Unjustly inducing or coercing the customers of a competitor to deal with one;

(d) Dealing with another party on such conditions as will unjustly restrict the business activities of said counterparty;

(e) Dealing with the counterparty by making use of one's superior bargaining position unjustly;

(f) Unjustly interfering with a transaction between an enterprise in competition with one in Japan or a corporation of which one is a shareholder or an officer and another transaction counterparty; or, if such enterprise is a corporation, unjustly inducing, instigating or coercing a shareholder or officer of such corporation to act against the corporation's interests.

The JFTC has made designations under Article 2(9)(vi) AMA in the General Designation $^{22}$ and in sector-specific special designations, for example for newspapers

20 For the importance Japanese authorities put on the (procedural) element of discussion see $\mathrm{T}$ Shiraishi, ‘A Baseline for Analyzing Exploitative Abuse of a Dominant/Superior Position’ (2013) 5 UT Soft Law Review 1, 6-7, available at <http://ssrn.com/abstract=2246558> (last accessed 20 August 2018), citing the TEPCO case.

$21 \quad$ Above n 10.

$22 \quad$ Above n 8. 
and large scale retailers in their relationship to their suppliers. ${ }^{23}$ In the General Designation, only paragraph 13 refers explicitly to a 'dominant bargaining position' ${ }^{24}$ More importantly, several other forms of 'unfair trading practices' enumerated in other items of Article 2(9) AMA and in the General Designation also concern 'unilateral conduct of non-dominant firms', such as discriminatory conduct, ${ }^{25}$ sales below $\operatorname{cost}^{26}$ or refusals to deal. ${ }^{27}$ These provisions - while not as such considered to be part of the rules on 'superior bargaining positions' in Japan - are relevant to the legal comparison in this contribution as forms of control over unilateral conduct by non-dominant firms. They are explained and illustrated in separate Guidelines, such as the 'Guidelines Concerning Distribution Systems and Business Practices under the Antimonopoly Act', last revised 16 June $2017,{ }^{28}$ or the 'Guidelines Concerning Unjust Low Price Sales under the Antimonopoly Act' of 2009. ${ }^{29}$

23 For newspapers, the special designation is the one on 'Specific Unfair Trade Practices in the Newspaper Business' (Fair Trade Commission Notification No 9 of 1999). For retailers, the special designation is the one on 'Specific Unfair Trade Practices by Large-Scale Retailers Relating to Trade with Suppliers' (Fair Trade Commission Notification No 11 of 2005); Takizawa and Arai indicate that this special designation is now 'de-facto invalid' (S Takizawa and K Arai, 'Abuse of Superior Bargaining Position: The Japanese Experience' (2014) 5 Journal of European Competition Law and Practice 557, 559 in fn 15).

$24 \quad$ Paragraph 13 of the General Designation provides that it is an unfair trade practice to "caus[e] a corporation which is one's transacting party to follow one's instruction in advance, or to get one's approval, regarding the appointment of officers of the said corporation [. . .], unjustly in light of the normal business practices by making use of one's dominant bargaining position over the party'.

25 AMA Article 2(9)(ii) (price discrimination) and General Designation paragraphs 3 and 4 (discrimination in other cases than those covered by Article 2(9)(ii) AMA).

26 AMA Article 2(9)(iii) (continuous supply of goods or services far below the cost incurred to supply them) and General Designation paragraph 6 (unjustly low price sales in other cases than those covered by Article 2(9)(iii) AMA).

27 General Designation paragraph 2 (refusal to deal). See also, eg, General Designation 10 (tying) and 11 (exclusive dealing).

$28 \quad$ Supra $\mathrm{n} 11$.

29 English translation available at <https://www.jftc.go.jp/en/legislation_gls/imonopoly_guidelines_files/unjustlowprice.pdf > (last accessed 20 August 2018) ('Guidelines on Unjust Low Prices’). 
The Guidelines on Unjust Low Prices distinguish between four categories. The first category are 'statutory low sales prices' under AMA Article 2(9)(iii), which prohibits 'supplying goods or services continuously for a consideration which is excessively below the costs required for the supply, thereby tending to cause difficulties to the business activities of other entrepreneurs' without justification. The Guidelines explain the statutory elements, namely: the cost standard ('variable-featured costs' which seek to approximate an Average Avoidable Cost standard), continuity (which includes repetition) and when below-cost prices 'tend to cause difficulty' to other entrepreneurs (a 'concrete possibility' is enough, actual effects need not be shown). The Guidelines do not set out any market power or share threshold, and unfair trade practices generally do not require any market power. However, note 9 of the Guidelines gives an example when there is a concrete possibility that below-cost prices cause difficulty:

For example, when an influential entrepreneur engages in price cutting, supplying goods at a price that is lower than the variable-featured costs, with the intention to exclude other entrepreneurs from the relevant market, and as a result, its sales quantity increases rapidly, making the price cutter the top seller in said market, such price cutting is regarded as being 'tending to cause difficulties to the business activities of other entrepreneurs' even if the business activities of the other entrepreneurs are not found to be facing difficulty in actuality. ${ }^{30}$

The Guidelines on Unjust Low Prices do not define what an 'influential entrepreneur' is. It may be that the definition in the Guidelines concerning distribution systems is applicable, which determine whether a firm is influential in the market by 'in the first instance judg[ing] by a market share of the firm, that is whether it has no less than 10 per cent or its position is within the top three in the market . . . 31 Justifications for prices below the threshold are, for example, changes in the input prices or the sale of perishable goods. $^{32}$

The second category are cases under General Designation paragraph 6, which prohibits 'unjustly supplying goods or services for a low consideration, thereby tending to cause difficulties to the business activities of other entrepreneurs in cases

\footnotetext{
$30 \quad$ Guidelines on Unjust Low Prices, n 29, 9 in n 9.

31 Guidelines concerning Distribution Systems (in the 2015 version), above n 11, 16 in $\mathrm{n} 7$.

32 Guidelines on Unjust Low Prices, n 29, 9-10.
} 
other than those covered by Article 2(9)(iii) AMA. This provision may apply even when neither the cost standard nor the continuity element of the statutory low sales prices under Article 2(9)(iii) AMA is proven. Whether the 'tending to cause difficulty' element is fulfilled will be decided on a case-by-case basis, taking similar factors into account as for the statutory low sales prices provision; it is said to be likely where an entrepreneur 'with a large market share' continuously charges low prices for a large quantity, or charges particularly low prices. ${ }^{33}$

The third category mentioned by the Guidelines are discriminatory prices and trading terms. ${ }^{34}$

Finally, the Guidelines explain that the prohibition of abuses of superior bargaining positions (Article 2(9)(v) AMA) may apply where an entrepreneur in such a position abuses it 'to force the other party to supply goods to said entrepreneur at a low price or to defray monetary contributions for improving the said entrepreneur's settlement of accounts'. ${ }^{35}$

To summarize: superior bargaining positions under Japanese law do not require dominance. The reference point is not the market power on a relevant market erga omnes, but the bargaining position inter partes.

\subsubsection{Germany}

The rules on unilateral conduct of non-dominant firms, or in the German terminology 'relative and superior market power' (relative and absolute Marktmacht) are today contained in $\S 20$ of the Act against Restraints of Competition (ARC), which will be discussed below. ${ }^{36}$ Rules on relative and superior market power have not always been

\section{$33 \quad$ Ibid, 10-11.}

34 See the applicable provisions above, n 25, and Guidelines on Unjust Low Prices, n 29, 11-12.

35 Guidelines on Unjust Low Prices, n 29, 11-12 (these Guidelines use the term dominant rather than superior bargaining position, but this is just a translation issue).

36 The following discussion of the German rules is largely based on my (more comprehensive) descriptions in F Wagner-von Papp, 'Comparative Antitrust Federalism and the Error-Cost Framework' in N Charbit and E Ramundo (eds), William E Kovacic: An Antitrust Tribute - Liber Amicorum Vol II (New York, Institute of Competition Law 2014) 23, 55-64; F Wagner-von Papp, 'Brauchen wir eine Missbrauchskontrolle von Unternehmen mit nur relativer oder überlegener 
part of the ARC. In the original ARC 1958, there were no rules on economic dependency at all. In 1973, a provision on relative market power, similar to what is now contained in $\S 20(1)$ ARC, was introduced into the Act. The reason for the introduction of this provision was the prohibition of resale price maintenance (RPM) for branded goods in the 1973 amendment. The anticipated mischief was that manufacturers of branded goods would otherwise de facto continue their RPM schemes by unilaterally terminating their agreements with distributors who undercut the former minimum, now recommended, prices. The provision on relative market power was, in other words, an attempt to address the Colgate problem - how to reconcile the prohibition of an agreement to adhere to vertically fixed prices with the freedom to terminate distribution relationships unilaterally.

Subsequent revisions of the ARC added more and more restrictive provisions, in particular with regard to relative market power on the demand side and superior market power in the horizontal relationship, culminating, at least for now, in what is today $\S 20$ ARC with the scope described below.

The German rules on unilateral conduct of non-dominant firms have been rearranged since the ICN Task Force Report was published, without, however, having been changed in substance since then.

The rules are now essentially contained in one provision, $\S 20 \mathrm{ARC}$ 2013/2017. § 20 ARC provides for two separate categories of alleged 'market power' below the threshold of dominance, so-called 'relative market power' in a vertical relationship between an undertaking and either its suppliers or customers; and 'superior market power' in the horizontal relationship between a large undertaking and its SME competitors.

\subsection{Relative market power}

Marktmacht?' in F Bien (ed), Das deutsche Kartellrecht nach der 8. GWB-Novelle (Baden-Baden, Nomos 2013) 95, 118-54. Here, I only want to outline the general approach in order to compare it to Japanese and US law. 
The first category, 'relative market power', is addressed in $\S 20(1)$, (2) ARC, which provide: ${ }^{37}$

$\S 20(1) \quad \S 19(1)$ in combination with $\S 19(2)$ no 1 [scil: the prohibition of abuses by a dominant undertaking, in particular by directly or indirectly unfairly impeding another undertaking or directly or indirectly treating another undertaking differently without objective justification] also applies to undertakings and associations of undertakings to the extent that small and medium undertakings [...] are dependent on the undertakings or associations in such a way that sufficient and reasonable opportunities to switch to other undertakings are unavailable to the small and medium undertakings (relative market power). The dependence on a customer [. . .] is presumed where this customer is regularly granted particularly advantageous conditions over and above the usual discounts on the price or other forms of consideration which are not granted to equivalent customers.

(2) $\S 19(1)$ in combination with $\S 19(2)$ no 5 [scil: the prohibition of abuses by a dominant undertaking, in particular by using its position to request from other undertakings advantages without objective justification] also applies to undertakings and associations of undertakings in the relationship to undertakings that are dependent on them.

Whether or not relative market power exists is determined decisively by the question whether the allegedly dependent undertaking has 'sufficient and reasonable opportunities to switch to other undertakings' on the relevant product and geographic market. The crucial question is what outside options are considered to be 'sufficient and reasonable'. From a competition policy perspective, it would make sense to consider sufficient and reasonable outside options to exist whenever there is effective competition on the relevant market, that is, when the market is not dominated. This, however, would reduce the scope of $\S 20(1)$, (2) ARC to cases of dominance. Clearly, this is not what the ARC has in mind; otherwise, all cases covered by $\S 20(1)$, (2)

37 Author's translation. Note that, first, the presumption in the second sentence of subsection 1 only applies to the dependence of a customer on a supplier (and not vice versa), and, second, that in subsection 1 the dependent undertaking has to be an SME, while in subsection 2 the dependent undertaking may also be a large undertaking. 
ARC would already be covered by the prohibition of abuses of dominance in $\S 19$ ARC. Instead, $\S 20(1)$, (2) ARC require an enquiry into the sufficiency and reasonability of outside options from the perspective of the allegedly dependent undertaking. On the other hand, however, an allegedly dependent undertaking may not rely on a dependence that is 'self-inflicted'. 38

This creates the following dilemma: where there is 'effective competition' on the relevant market, which presupposes that customers or suppliers on the relevant market generally have sufficient and reasonable outside options, and the particular undertaking in question nevertheless has no sufficient or reasonable outside options, this lack of outside options necessarily must be owed to path-dependencies resulting from choices previously made by the 'dependent' undertaking. They could therefore be said to be self-inflicted. The case law seems to resolve this dilemma by stating that such self-infliction will be disregarded if the choice leading to the subsequent dependency was also in the interest of the other undertaking, for example where the dependent undertaking makes transaction-specific investments that are desired by the other undertaking $;{ }^{39}$ more recently, the case law has taken up this question in the interest-balancing part of the framework. ${ }^{40}$

Relative market power is considered to exist in particular in three case categories:

(1) 1. where a distributor, especially a retail outlet, is dependent on 'must stock products' by a given supplier, in particular where customers expect 'any decent retailer' to stock these products, because they are the 'top brand' or one of a group of top brands (or, conversely, a supplier is dependent on a particular distributor $) ;{ }^{41}$

38 J Nothdurft, '§ 20', in E Langen and H-J Bunte (eds), Kommentar zum Deutschen und Europäischen Kartellrecht (13th edn, Cologne, Luchterhand 2018) para 38.

$39 \quad$ Ibid, para 38

40 Ibid, citing BGH - Porsche Tuning [6 October 2015] KZR 87/13, and BGH - Jaguar Vertragswerkstatt [26 January 2016] KZR 41/14.

41 The paradigm example for this case category is the Rossignol case: the ski manufacturer Rossignol terminated a business relationship with a sports shop. The sports shop claimed that customers expected any decent retailer to stock Rossignol skis. Rossignol had a market share of only about 8 per cent, and the Court found there to be 'considerable competition' between suppliers. Nevertheless, the Court decided the sports shop depended on stocking Rossignol skis because of the 
(2) 2. where dependence is 'scarcity induced'; 42 and

(3) 3. where the dependence is owed to the 'unique relationship' between the supplier and the distributor, in particular where the parties have made transaction-specific investments, so that the dependent undertaking is vulnerable to opportunistic conduct. ${ }^{43}$

However, this list of case categories is not exhaustive. With regard to relative market power on the demand side, in particular the relationship between powerful retail chains and their suppliers, none of the categories above are directly pertinent, and the Bundeskartellamt, following proposals in the literature, has suggested adding a further category of 'demand-side dependence'. ${ }^{44}$

customers' expectations, raised by Rossignol's advertising 'which can give branded goods a specific market position with the result that the customer feels unable to substitute the goods with other goods', and that Rossignol had a duty to deal with the sports shop. BGH [20 November 1975] KZR 1/75 (an English translation of an extract of the decision is available at <http://www.utexas.edu/law/academics/centers/transnational/work_new/german/case.php?id=1488> (last accessed 20 August 2018)). In interpreting this case, one should bear in mind that Rossignol's stated reason for refusing to deal with the sports shop in question was that the shop was selling Rossignol skis too cheaply. This case therefore directly implicated the mischief which the legislator had sought to avoid by introducing the prohibition, namely the circumvention of the prohibition of resale price maintenance by unilaterally cutting off undertakings that undercut recommended resale prices.

42 The paradigm example, which was already mentioned in the report accompanying the introduction of the provision on relative market power (Bundestagsdrucksache 7/765, at 10), was the supply of independent petrol stations during the oil crisis. Because independent petrol stations in an oil crisis have no sufficient outside options, vertically integrated petroleum companies were said to have a duty to apportion the available supplies in a non-discriminatory manner between its own branded petrol stations and independent petrol stations.

43 This category is particularly relevant for franchised car dealers that have specialized in a particular make.

44 See, eg, Bundeskartellamt - EDEKA [3 July 2014] B2-58/09, available at $<$ http://www.bundeskartellamt.de/SharedDocs/Entscheidung/DE/Entscheidungen/Missbrauchsaufsicht/ 2014/B2-58-09.pdf?_blob=publicationFile \&v=4> (last accessed 20 August 2018) (in German), largely upheld in BGH [23 January 2018] KVR 3/17, ECLI:DE:BGH:2018:230118BKVR3.17.0; J Nothdurft, '§ 20', in E Langen and H-J Bunte (eds), Kommentar zum Deutschen und Europäischen Kartellrecht (13th edn, Cologne, Luchterhand 2018) paras 57-65. 
In contrast to Japanese law, § 20(1) ARC only protects dependent undertakings if they are SMEs. ${ }^{45}$ However, $§ 20(2)$ ARC, like Japanese law, protects small, medium-sized and large dependent suppliers against requests for advantages by customers with relative market power. ${ }^{46}$

Whether any particular conduct constitutes an unfair impediment or unjustified differential treatment is decided in a comprehensive interest-balancing exercise with particular regard to the goals of the ARC, which pursues freedom of competition. Despite its vacuousness, this formula can be found in all decisions on $\S 20$ ARC.

Undertakings with relative market power may, in particular, be limited in their freedom to choose their trading partners: they may have a duty to deal with dependent undertakings, for example in cases of must-stock items or scarcity induced dependency. In principle, however, even dominant undertakings and those with relative market power have the freedom to choose their trading partners, and it would be wrong to assume that German courts lightly restrict this freedom ${ }^{47}$ In cases where the dependency derives from the unique relationship between the parties - such as long-term dealerships or franchises - the consequence would usually be that sufficient notice must be given before the contract can be brought to an end.

The prohibition against 'tapping suppliers', in $\S 20(2)$ ARC, shows - like the Japanese provisions - a particular concern regarding buyer power in particular by

45 This was not always the case. From its introduction in 1973 to the 5th Amendment of the ARC in 1989 large dependent undertakings were also protected by the predecessor provision of today's § 20(1) ARC (Fünftes Gesetz zur Änderung des Gesetzes gegen Wettbewerbsbeschränkungen, 22 December 1989, (1989) Bundesgesetzblatt Part I 2486, entry into force 1 January 1990; see the explanatory memorandum, Bundestagsdrucksache 11/4610, at 21-2).

46 Again, this was not always the case. Before 2007, the predecessor provision of today's $\S 20(2)$ ARC was limited to the protection of dependent SME suppliers. In 2007, the SME requirement was struck out on a temporary basis; a sunset provision in the 2007 Act led to the reinstatement of the SME requirement on 1 January 2013, before the 8th Amendment struck out the SME requirement on a permanent basis (contrary to the initial Bill for the 8th Amendment).

47 BGH -Werbeanzeigen [31 January 2012] KZR 65/10; BGH - Qualitative Selektion [28 June 2005] KZR 26/04; BGH - Modellbauartikel III [8 March 1983] KZR 1/82; BGH - SBVerbrauchermarkt [24 March 1981] KZR 2/80; also cf BGH - EH-Partner-Vertrag [15 April 1986] KVR 3/85. 
large retailers. The provision was introduced to address concerns that large retailers would demand preferential treatment from their suppliers, thus exploiting suppliers and distorting competition between the large, favoured retailer and small, disfavoured retailers. Some see the purpose of the 'tapping' provision primarily in the distortive effects that the granting of special conditions has on the horizontal relationship between the undertaking with relative market power and its competitors; others extend the protective purpose to the vertical relationship between the dependent supplier and the undertaking with relative market power. ${ }^{48}$ Despite the prominence given to these concerns in the legislative process, there is very little case law. Even though more than 30 years have passed since its introduction, the scope of the provision remains unclear. The legislative materials mention (not unlike Article 2(9)(v) AMA and the Japanese Guidelines on Superior Bargaining Position) slotting fees and other payments or services that were not related to the 'merit' of the relationship such as the quantity of goods purchased or services provided. The focus in the legislative materials and in current commentary is usually not on the purchase price as such, but on non-price components of the transaction or payments other than the purchase price. In practice, the only applications of the provision of any relevance have been retroactive discounts after mergers ('wedding gifts'). ${ }^{49}$

This reveals a general flaw not only in this provision, but in many of the provisions on relative market power. The undertaking with relative market power and the dependent undertaking are in a contractual relationship with each other (or intend to enter into one). One of the parties has more bargaining power than the other. Even if we prohibit the exercise of this bargaining power in a particular form (eg, slotting fees, wedding gifts), this does not make the bargaining power go away. If non-price conditions or payments other than the purchase price are scrutinized, the bargaining power will be

$48 \quad$ See the discussion in BGH - Konditionenanpassung [24 September 2002] KVR 8/01 with a case note by F Wagner, 'Konditionenanpassung' [2003] Entscheidungen im Wirtschaftsrecht 331 § 20 GWB 1/03.

49 See the decisions BGH - Konditionenanpassung (n Error! Bookmark not defined.) and BGH - Hochzeitsrabatt [23 January 2018] KVR 3/17, ECLI:DE:BGH:2018:230118BKVR3.17.0. For a discussion of the EDEKA case (up to the OLG Düsseldorf level) and the subsequent legislative reaction in 2017, see L Murach, 'Anzapfverbot' in C Kersting and R Podszun (eds), Die 9. GWBNovelle (Munich, CH Beck 2017) 45-55. 
exercised in the negotiation about the purchase price. Whether this is necessarily in the interest of the dependent undertaking is questionable.

If one wanted to prevent the exercise of existing bargaining power, it would not be enough to control particular emanations; one would have to regulate comprehensively all aspects of the contractual relationship, including the adequacy of the price. It is easy to see that such a comprehensive regulation of contractual relationships of nondominant parties, including the adequacy of the consideration, is not desirable in a free market economy. Yet without such a comprehensive regulation, any attempt to prohibit partial emanations of the underlying bargaining power are bound to resemble a game of whack-a-mole.

\subsection{Superior market power}

The second category of heightened power that subjects undertakings to control of their unilateral conduct is 'superior market power' in $\S 20(3)$, (4) ARC, where the alleged 'market power' is in the horizontal relationship between the undertaking and its small or medium-sized competitors. § 20(3), (4) ARC provide: ${ }^{50}$

(3) Undertakings with superior market power vis-à-vis small and mediumsized competitors may not use their market power to directly or indirectly impede such competitors unfairly. An unfair impediment in the meaning of the first sentence exists in particular where an undertaking

1. 1. offers food products [...] below the purchase price, or

2. 2. offers other goods or services more than occasionally below the purchase price, or

3. 3. demands a higher price for goods or services from small and medium undertakings with which it competes on a downstream market for the distribution of these goods or services than the prices it offers itself on the downstream market,

unless there is an objective justification. Purchase price in the meaning of the second sentence is the price agreed between the undertaking with superior

$50 \quad$ Author's translation. 
market power and its supplier for procuring the product or service, to which sufficiently predictable general rebates are applied pro rata, unless something different is agreed with regard to specific products or services. Offering food products below the purchase price is objectively justified where it helps to sell them sufficiently quickly to prevent the goods from perishing or becoming unsalable, or in similarly serious cases.

(4) Where specific facts give rise to an inference that an undertaking has abused its position in the meaning of subsection 3, it is for that undertaking to refute the inference and to disclose circumstances in its sphere whose pleading is impossible for the competitor in question [. . .] but easily and reasonably possible for the undertaking.

Undertakings with superior market power are prohibited from unfairly using their power to impede its SME competitors. In particular, they are prohibited from selling below their own purchase price and from margin squeezing. Particularly controversial in Germany are the provisions on sales below cost. When the legislator introduced the prohibition into the Act against Restraints of Competition, the Federal Court of Justice originally interpreted the provision (sensibly) to be applicable only where there was a sufficient likelihood of lasting harm to competition. ${ }^{51}$ The legislator intervened to overturn this decision and explicitly prohibited any sale below cost by an undertaking with superior power, unless it was practised only occasionally or was objectively justified. ${ }^{52}$ Faced with a clearly expressed legislative intent, the Federal Court of Justice grudgingly gave in. ${ }^{53}$ The statutory provision has since not only been amended to include even the occasional sale below cost for food products, but it was renewed in 2013, after a sunset clause made the provision temporarily inapplicable, and was made permanent in 2017. However, a decision by the Court of Appeals in Düsseldorf had held, under the pre-2017 version of the rule, that general promotional rebates given by a manufacturer without any specific designation may be allocated by

\footnotetext{
51 BGH - Hitlisten-Platten [4 April 1995] KZR 34/93.

52 Bundestags-Drucksache (Parliamentary Documents) No 13/10633, 72 (committee report and recommendation).
}

53 BGH - Wal-Mart [12 November 2002] KVR 5/02. 
the retailer to any product as desired, ${ }^{54}$ and this ruling made the sales below cost provision in most cases inapplicable. The 2017 amendment to the ARC inserted the definition of 'purchase price' in clause 3 of $\S 20(3)$ ARC (as quoted above), which now removes the possibility of such an interpretation.

In terms of competition advocacy, the Monopoly Commission has consistently argued against the prohibition of sales below cost (and, though less strenuously, against the margin squeeze provision). ${ }^{55}$ The Bundeskartellamt, in contrast, has equivocated: while it has always protested that the provision may be counterproductive as a matter of competition policy, it has nevertheless imposed substantial individual fines in the Rossmann case, and, when the appeals court quashed the fine, argued before the legislator that the provision should be reinforced to overcome the limitations imposed by the Rossmann judgment, a plea that proved ultimately successful in the 2017 amendment. $^{56}$

\subsubsection{Function of the rules and common themes in Germany and Japan}

Before examining whether the United States has any rules that are functionally equivalent to the rules on superior bargaining power and related rules on unilateral conduct in the absence of dominance in Japan or on relative or superior market power in Germany, it is necessary to identify the function these rules serve. This is a difficult task. The reason why it is so difficult to identify their function is that the rules do not seem to serve one well-defined function.

54 OLG Düsseldorf - Rossmann [12 November 2009] VI-2 Kart 9/08 OWi (affirmed by the BGH).

55 See, eg, Monopolkommission, Die 8. GWB-Novelle aus wettbewerbspolitischer Sicht, Sondergutachten 63 (2012), paras 79-91, available at <http://monopolkommission.de/images/PDF/SG/s63_volltext.pdf> (last accessed 20 August 2018); see also the further references in F Wagner-von Papp, 'Brauchen wir eine Missbrauchskontrolle von Unternehmen mit nur relativer oder überlegener Marktmacht?' in F Bien (ed) Das deutsche Kartellrecht nach der 8. GWB-Novelle (Baden-Baden, Nomos 2013) 95, 96-7 in fn 4.

56 For details before the 2017 amendment, see Wagner-von Papp, previous footnote, 131-6. For details in the 2017 amendment, see L Murach, 'Verkauf unter Einstandspreis' in C Kersting and R Podszun (eds), Die 9. GWB-Novelle (Munich, CH Beck 2017) 57-67. 
Partly they seek to protect parties in an incomplete contract against ex post opportunism: changing the terms of an ongoing contractual relationship after one party has made transaction-specific investments à la Williamson. ${ }^{57}$ To this extent one can understand the rules as quasi-contract rules - as a specific emanation of the duty of good faith in long-term contracts.

This cannot, however, explain rules such as the ones against sales below cost, margin squeeze or refusals to deal. These categories are well known from abuse of dominance cases, where they seek to prevent anticompetitive exclusion of efficient competitors. The theory of harm of exclusion as a raison d'être is sometimes also ascribed to the rules on non-dominant firms. This is hardly a compelling argument because exclusion of efficient competitors is unlikely in the absence of dominance. Here, however, we are only asking what functions the rules purport to serve, not whether the rules are well-suited to fulfil the function.

Some declare openly that the justification for the rules on the control of unilateral conduct below the threshold of dominance is SME protection, occasionally coupled with the 'universal service' argument that SMEs are better suited to ensure stability of supply in rural areas. ${ }^{58}$ Such outright engineering towards a particular market structure - which has been abandoned in mainstream antitrust analysis of dominance rules - is particularly visible when it comes to the retail sector, the protection of 'mom-and-pop' stores against supermarket chains.

Five further aspects of the rules in Japan and Germany are worth noting.

First, one of the core concerns is demand-side market power. In Japan, this is clearly visible in the statutory text of Article 2(9)(v)(a)-(c) AMA, and throughout the Guidelines and in the enforcement practice that focusses on suppliers of the large retailers, as well as the (now de facto largely superseded) Special Designation for

\footnotetext{
$57 \quad$ OE Williamson, The Economic Institutions of Capitalism (New York, The Free Press 1985).

58 For German law, see the Government's Explanatory Memorandum, Bundestags-Drucksache 17/9852, 20 (acknowledging the 'SME policy dimension'); L Murach, 'Verkauf unter Einstandspreis' in C Kersting and R Podszun (eds), Die 9. GWB-Novelle (Munich, CH Beck 2017) 57, 66-7; for Japanese law, see E Kameoka, Competition Law and Policy in Japan and the EU (Cheltenham, UK and Northampton, MA, USA, Edward Elgar 2014) 87 ('antimonopoly law crosses over into social policy and becomes an instrument by which to protect smaller businesses').
} 
Large-Scale Retailers. In Germany, the statutory provisions indicate the same concern: the second sentence of $\S 20(1)$ ARC, and $\S 20(2)$ ARC deal explicitly with demand-side market power, and the legislative history shows that concerns about the relationship between large retailers and their suppliers dominated the discussion in Germany as well.

Second, both Germany and Japan impose an obligation not to discriminate absent a sufficient justification on non-dominant firms. ${ }^{59}$

Third, both in Germany and in Japan, sales below cost prohibitions are extended beyond predatory pricing by dominant firms. In Germany, it is undertakings with superior market power that are the addressee of the prohibition, and in Japan it is theoretically any undertaking that can be caught up, although the requirement that there has to be a concrete possibility of affecting other businesses will usually mean that the undertaking has to exceed at least the threshold of an 'influential enterprise', which appears roughly to mean a market share of 10 per cent or more.

Fourth, both in Japan and Germany, the definition of dependence as well as the prohibited conduct is vague. Whether there is dependence or an abuse is determined by a comprehensive consideration of various factors.

Fifth, it may be that part of the explanation for the existence of these rules, and why antitrust enforcers generally like them, is that it relieves enforcers - authorities and private plaintiffs alike - from the need to establish dominance. Establishing dominance can be a difficult task - one has to define the relevant market, identify the competitors and determine their market share. These are highly fact-intensive issues. Private plaintiffs in particular may not be able to collect these facts in the absence of a discovery procedure. It is much easier to show that a particular undertaking is dependent on another undertaking. To the extent enforcement of the rules on economic dependency is applied to cases in which the undertaking in question is actually dominant, but could not be proven to be so, the rules reduce the number of false negatives of the more stringent prohibitions against abuses of dominant positions.

59 Japan: Articles 2(9)(v)(ii) AMA (price discrimination), 2(9)(v)(vi)(a) AMA in combination with General Designation 3 and 4; Germany: § 20(1) in combination with § 19(2) no 1 ARC. 


\subsubsection{United States of America}

According to the ICN Task Force Report, the United States' response to the questionnaire was adamant that the US had neither specific provisions on abuses of superior bargaining positions, nor any provisions in its competition law or general legal provisions that would be applicable to abuses of superior bargaining positions. ${ }^{60}$ As I will argue in this section, this was outright wrong, or at a minimum misleading. Furthermore, the US response was clear that controlling unilateral conduct below the threshold of dominance would be bad policy. ${ }^{61}$ As I will argue in the next part of the chapter, this is correct.

The denial of the existence of rules that are equivalent to the rules on the abuse of superior bargaining positions is arguably due to response bias: the question, which explicitly sought functional equivalents to provisions on abuses of superior bargaining positions, was apparently misunderstood. Alternatively, it is possible that the answer was skewed to make it appear as if the law in action conformed to the normative recommendation in the United States' submission. ${ }^{62}$

While it is true that there is no separate provision in US antitrust law which deals specifically with abuses of a position with some level of market or bargaining power below the threshold of monopoly power (or at least a dangerous probability of acquiring monopoly power), there are numerous provisions that apply to situations in which jurisdictions such as Japan or Germany would apply their provisions on abuses of superior bargaining positions or other unfair trade practices. Concerns typically dealt with by these rules in Japan and Germany were identified above as being:

\footnotetext{
$60 \quad$ ICN Task Force Report, at 10.

$61 \quad$ ICN Task Force Report, at 17.
}

62 A cynic could find an indication that the ICN Task Force Report may have been deliberately less than forthcoming in the Report by the Antitrust Modernization Commission, which noted, in explaining the desirability of a repeal of the Robinson-Patman Act (RPA), that the '[c]ontinued existence of the RPA also makes it difficult for the United States to advocate against the adoption and use of similar laws against U.S. companies operating in other jurisdictions'. (Antitrust Modernization Commission, Recommendation and Report (April 2007) iii, available at <http://govinfo.library.unt.edu/amc/report_recommendation/amc_final_report.pdf>) (last accessed 20 August 2018). Not mentioning the RPA made the argument certainly easier. 
1. 1. non-discrimination rules;

2. 2. demand-side market power;

3. 3. sales below cost; and

4. 4. the protection of parties in incomplete contracts that made transactionspecific investments.

With regard to the prohibition of discrimination, the most obvious equivalent in the United States is the Robinson-Patman Act (RPA). ${ }^{63}$ It is impossible here to go into in Bork's words - 'Robinson-Patman's seemingly endless complexities and perversities' ${ }^{64}$ For present purposes, it suffices to outline that the RPA provides that it is unlawful

to discriminate in price between different purchasers of commodities of like grade and quality [. . . ] where the effect of such discrimination may be substantially to lessen competition or tend to create a monopoly [. . .] or to injure, destroy, or prevent competition with any person who either grants or knowingly receives the benefit of such discrimination or with customers of either of them,

unless the differential prices are justified by cost differences, recognition of which may be limited by the FTC, or the price differences are due to price changes

in response to changing conditions affecting the market for or the marketability of the goods concerned, such as but not limited to actual or imminent deterioration of perishable goods, obsolescence of seasonal goods, distress sales under court process, or sales in good faith in discontinuance of business in the goods concerned. ${ }^{65}$

Section 2(b) RPA provides for a meeting-competition defence. ${ }^{66}$

A 'child of the depression ${ }^{67}$ and meant to protect 'mom-and-pop' stores against chain stores, ${ }^{68}$ today the RPA is unloved by US American antitrust lawyers, ${ }^{69}$ because it

63 15 U.S.C. $\$ 13$. For a detailed history of the development of the application of the RobinsonPatman Act in the law in action, see DD Sokol, 'Analyzing Robinson-Patman' (2015) 83 George Washington Law Review 2064.

64 RH Bork, The Antitrust Paradox: A Policy at War with Itself (New York, The Free Press 1978/1993) 383.

65 15 U.S.C. $\S 13(\mathrm{a})$.
$66 \quad 15$ U.S.C. $\$ 13(\mathrm{~b})$.
$67 \quad$ RH Bork, The Antitrust Paradox: A Policy at War with Itself (New York, The Free Press
1978/1993) 382. 
does not fit into the modern conception of antitrust laws as pursuing single-mindedly total welfare and focussing on protecting 'competition, not competitors'. To the contrary, in its traditional interpretation the RPA protects competitors rather than competition, ${ }^{70}$ much like the provisions on superior bargaining positions in Germany and Japan.

This lack of love for the RPA has manifested itself in several unsuccessful attempts to repeal the Act. ${ }^{71}$ The Department of Justice stopped RPA enforcement in the mid1970s. ${ }^{72}$ The FTC was slower to give up using the RPA, but it has brought no case since 2000, and even that one case "might be better characterized as an exclusive

See Volvo Trucks North America, Inc v Reeder-Simco GMC, Inc, 546 US 164, 175 (2006) and the further references in F Wagner-von Papp, 'Comparative Antitrust Federalism and the Error-Cost Framework' in N Charbit and E Ramundo (eds), William E Kovacic: An Antitrust Tribute - Liber Amicorum Vol II (New York, Institute of Competition Law 2014) 23, 64 in fn 185; for more detail, see DD Sokol, ‘Analyzing Robinson-Patman' (2015) 83 George Washington Law Review 2064, 2068-70.

69 RH Bork, The Antitrust Paradox: A Policy at War with Itself (New York, The Free Press 1978/1993) 385, noted as early as 1978 that 'no other antitrust statute has been subjected to so steady a barrage of hostile commentary as [the RPA]', amounting to 'a cascade of vituperation'.

70 Antitrust Modernization Commission, Recommendation and Report (April 2007) iii, available at <http://govinfo.library.unt.edu/amc/report_recommendation/amc_final_report.pdf > (last accessed 20 August 2018); RH Bork, The Antitrust Paradox, cited above, 383; FM Scherer and D Ross, Industrial Market Structure and Economic Performance (3rd edn, Boston MA, Houghton Mifflin 1990) 509 ('There is virtual unanimity among students of the act that, in sharp contrast to the other antitrust laws, its motivation was mainly a desire to limit competition, not to enhance it'); DD Sokol, 'Analyzing Robinson-Patman' (2015) 83 George Washington Law Review 2064, passim; but see Volvo Trucks North America, Inc v Reeder-Simco GMC, Inc, 546 US 164, 180-81 (2006) (stating that interbrand competition is antitrust's main concern, that the RPA does not substantially depart from this concern, and that 'we would resist interpretation geared more to the protection of existing competitors than to the stimulation of competition'.).

71 Antitrust Modernization Commission, Recommendation and Report (April 2007) iii, available at <http://govinfo.library.unt.edu/amc/report_recommendation/amc_final_report.pdf> (last accessed 20 August 2018), itself recommending the repeal, notes the previous attempts in 1955, 1969 and 1977.

72 DD Sokol, ‘Analyzing Robinson-Patman’ (2015) 83 George Washington Law Review 2064, 2075 . 
dealing case masquerading as a Robinson-Patman case'. ${ }^{73}$ However, private enforcement of the RPA remains a reality to this day. ${ }^{74}$

Courts have also clipped the wings of the RPA by interpreting the prohibition narrowly and the defences broadly. ${ }^{75}$ Primary-line discrimination, that is, the charging of differential (discounted) prices by a seller that injures competing sellers has de facto been reduced to cases of predatory pricing that can be addressed under section 2 Sherman Act; even under the RPA, below-cost pricing and a reasonable prospect of

\section{$73 \quad$ Ibid, 2073 in fn 77.}

74 Sokol (ibid, 2094) identified 113 post-1993 Robinson-Patman Act cases. While primary-line cases have hardly ever been successful after Brooke Group (see text following this footnote), 28 of the 94 post-1993 secondary-line cases in Sokol's dataset have been successful for the plaintiff. As cases more often settle before trial (Sokol, at 2086), especially if they look promising for the plaintiff, this understates the current impact of Robinson-Patman Act. Also, Sokol's dataset was compiled from the ALLFEDS database in Westlaw, so that litigation of Robinson-Patman-like issues in state courts is not captured. Sokol concludes (at 2099) that 'firms must still incorporate some low level Robinson-Patman risk into their planning, which may be costly and potentially lead to less efficient outcomes that may hurt consumers'.

75 For an example of a narrow interpretation of the prohibition, see Volvo Trucks North America, Inc v Reeder-Simco GMC, Inc 546 US 164 (2006) (holding that there was no unlawful secondary-line price discrimination where dealers engaged in competitive bidding to supply heavy-duty trucks according to customer specifications, and where only the successful Volvo dealer would approach Volvo for (further) price concessions, because by the time the discriminatory concession was granted, the dealers were no longer competing for the transaction (no contemporaneous competing for the same customer); also adding a requirement that the favoured customer have market power or some 'resemblance to large independent department stores or chain operations'). For an example of a broad interpretation of the defences, see Gorlick Distribution Centers v Car Sound Exhaust System 723 F3d 1019 (following the holding in Automatic Canteen Co of America v FTC 346 US 61 (1953) that under RPA 2(f) knowledge of receiving more favourable concessions than others was insufficient where there was no proof that the recipient knew that the person granting the concessions had no defence under the RPA). 
recoupment must be shown (in addition to differential pricing). ${ }^{76}$ Brooke Group has largely eliminated successful primary-line cases. ${ }^{77}$

With regard to secondary-line cases, in which the seller charges higher prices to a disfavoured purchaser than to a favoured purchaser who competes with the disfavoured purchaser, dicta in Brooke Group that the RPA is to be interpreted, to the extent possible, in accordance with the goals of the antitrust laws generally were reaffirmed and strengthened by the 2006 Volvo Trucks decision. ${ }^{78}$ While Volvo Trucks affirmed both that '[a] hallmark of the requisite competitive injury [. . .] is the diversion of sales or profits from a disfavored purchaser to a favored purchaser' ${ }^{79}$ and that the Morton Salt 'inference of competitive injury may arise from evidence that a favored competitor received a significant price reduction over a substantial period of time', ${ }^{80}$ it has introduced a - not very clearly defined - market power threshold for the favoured purchaser before the disfavoured purchaser can rely on the inference of competitive injury. ${ }^{81}$ Volvo Trucks equivocates. On the one hand, it does not clearly disavow, and indeed continues to rely upon, previous case law that explicitly did not require harm to competition under the RPA and let harm to a single competitor suffice. On the other hand, it appears to move the competitive injury assessment towards a harm-to-competition analysis. The market power requirement is new to RPA claims, but not well developed - dominance does not appear to be necessary; some degree of buyer power similar to that of chain stores appears to be sufficient. The vagueness of the new standard has created some confusion in the courts below. The Third Circuit complained: ${ }^{82}$

\footnotetext{
76 Brooke Group v Brown \& Williamson Tobacco 509 US 209, 220-21 (1993). For a recommendation to this effect, see RH Bork, The Antitrust Paradox: A Policy at War with Itself (New York, The Free Press 1978/1993) 386.

77 DD Sokol, ‘Analyzing Robinson-Patman’ (2015) 83 George Washington Law Review 2064, 2079-81, 2089, 2094-5, 2099.

Volvo Trucks North America, Inc v Reeder-Simco GMC, Inc 546 US 164 (2006).

79 Volvo Trucks, 177 (citing FTC v Sun Oil 371 US 505, 518-9 (1963)). 
The RPA places the federal courts in an inescapable Catch-22. We are asked to apply the RPA, a statute that 'is fundamentally inconsistent with the antitrust laws,' Antitrust Modernization Commission, Report and Recommendations 312 (2007), in a fashion that is 'consistent[ ] with the broader policies of the antitrust laws.' Volvo Trucks [. . .] This conundrum is bound to create confusion for judges called upon to apply the RPA in a host of settings.

As one commentator has pointed out, some post-Volvo Trucks courts have simply ignored the ruling, others have reduced Volvo Trucks largely to its facts, and yet others ${ }^{83}$ have held it to narrow the scope of secondary-line cases under the RPA substantially. ${ }^{84}$ Accordingly, a number of private plaintiffs have continued to succeed even in cases in which there was no harm to competition but only to competitors.

Moreover, even if the trend to limiting the RPA continues on the federal level, there are state statutes similar to the RPA in many states, which either prohibit discrimination generally ${ }^{85}$ or for particular industries. ${ }^{86}$ While these are often interpreted in line with federal precedent, this is not automatically the case.

83 Eg, ibid; Toledo Mack Sales \& Service v Mack Trucks 530 F3d 204 (3d Cir 2008); Smith Wholesale v RJ Reynolds Tobacco 477 F3d 854 (6th Cir 2007).

$84 \quad$ BO Bruckmann, 'Volvo Seven Years Later: Williams v. Duke Energy International, Inc.' [February 2013] The Antitrust Source 1, 4-5.

85 See American Bar Association (ABA) Section of Antitrust Law, State Antitrust Practice and Statutes, Vol I-III (5th edn, Chicago, ABA Book Publisher 2014), answers to survey query 13.a. See, eg, Arkansas 5-15-19 (Arkansas Unfair Practices Act is 'analogous to and [. . .] modeled after' the RPA); California 6-30-39 (discussing the Californian Unfair Practices Act, whose 'proscriptions [...] are different from those found in the [RPA]', but which '[n]onetheless has been analogized to Section 2 of the [RPA]'; see also California 6-41-43 for some variations for cigarettes, dairy products and motor vehicle fuels); Colorado 7-14-16 (Colorado Unfair Practices Act 'is an elaborate price discrimination [. ..] statute'); and so on.

86 ABA Section of Antitrust Law, State Antitrust Practice and Statutes, Vol I-III (5th edn, Chicago, ABA Book Publisher 2014), answers to survey question 13.c. See, eg, Alabama 2-25-32 (discussing prohibitions of price discrimination regarding motor fuel, 'sale of motor vehicles, light industrial equipment and heavy equipment'); Arkansas 5-20-23 (discussing, in addition to the general Arkansas Unfair Practices Act prohibition, prohibitions against rebates and concessions in the purchase of cigarettes, dairy (though no cases are reported), fuel, 'manufactured products, coal, oil or dressed beef'); and so on. 
The RPA even shares the concern about buyer power that we also saw in Germany and Japan. Section 2(f) of the RPA makes it unlawful 'for any person engaged in commerce, in the course of such commerce, knowingly to induce or receive a discrimination in price which is prohibited by this section'. ${ }^{87}$ The RPA was, after all, in particular aimed at powerful buyers in the form of chain stores. However, Scherer has pointed out that actual enforcement of the RPA did not reflect Congress's priority: 'Out of the more than 1,100 Robinson-Patman cease-and-desist orders issued by the Federal Trade Commission between 1936 and 1966, only thirty were brought under Section 2(f). ${ }^{88}$ The reason for this discrepancy is attributed to the requirement that the buyer must know not only that it receives more favourable treatment, but also that they receive illegal favourable treatment. ${ }^{89}$

The prohibition of sales below cost by non-dominant firms in Germany and Japan does not have an equivalent on the federal level in the US. However, in many states there are statutes that ban sales below cost either generally or in specific industries. ${ }^{90}$ Such rules are particularly frequent in the dairy and fuel sectors - two sectors in which sales below cost (or margin squeeze) provisions are often applied in Germany as well.

With regard to the protection of the 'dependent' party in incomplete contracts, such as franchisees, two different approaches can be observed in the US.

First, some courts have considered a post-contractual 'lock-in' of consumers in a long-term relationship such that the relevant market is reduced to a single-brand

$87 \quad 15$ U.S.C. $\S 13$ (f). Not all state unfair practices acts contain provisions equivalent to section 2(f) RPA. See, eg, the California and Colorado statutes (n 85).

88 FM Scherer and D Ross, Industrial Market Structure and Economic Performance (3rd edn, Boston MA, Houghton Mifflin 1990) 511.

89 Ibid. The requirement derives from Automatic Canteen v FTC 346 US 61 (1953), and was applied, eg, in Gorlick Distribution Centers v Car Sound Exhaust System 723 F3d 1019, 1022-4 (9th Cir 2013).

90 See Organisation for Economic Co-operation and Development (OECD), Resale below Cost Laws and Regulations, DAF/COMP(2005)43 (23 February 2006), 171-82, available at <http://www.oecd.org/regreform/sectors/36162664.pdf> (last accessed 20 August 2018), see also ABA Section of Antitrust Law, State Antitrust Practice and Statutes, Vol I-III (5th edn, Chicago, ABA Book Publisher 2014), answers to survey question 13.a.10. 
aftermarket. ${ }^{91}$ The same reasoning has been applied to lock-in of franchisees into the relationship with their franchisors. ${ }^{92}$ The reasoning is that once a long-term contract is concluded, the customer is 'locked into' the contract: it is impossible to switch to another brand. Accordingly, the relevant market is reduced to that particular brand. Since the relevant market is reduced to one brand, this brand has a monopoly on the aftermarket, and section 2 Sherman Act can be applied. There is, however, no lock-in where the customer has voluntarily locked herself into the contract; ${ }^{93}$ the decisions that found a lock-in have usually built on terms that were at least not obvious to the consumer when entering into the contract. ${ }^{94}$ Decisions using this reasoning have been criticized for misinterpreting post-contract bargaining power as market power, and confusing antitrust law with contract law. ${ }^{95}$ Part 10.3 of this chapter will come back to this point.

Secondly, there are franchisee protection statutes both on the federal level (for gasoline and car dealerships) and on the state level (some of them industry-specific, others general) that protect franchisees especially against termination without sufficient notice. ${ }^{96}$ The effect of these statutes is not unlike that of the German application of $\S 20(1)$ ARC, for example, to car dealerships.

$91 \quad$ See, eg, Newcal Industries v Ikon Office Solution 513 F3d 1038 (9th Cir 2008), cert den 129 SCt 2788 (2009) (Rule 12(b)(6) decision); In re Apple \& AT\&TM Antitrust Litigation, 596 F Supp2d 1288, 1302-6 (ND Cal 2008); Datel Holdings v Microsoft 712 F Supp2d 974, 985-90 (ND Cal, 2010).

92 WS Grimes, 'Market Definition in Franchise Antitrust Claims: Relational Market Power and the Franchisor's Conflict of Interest' (1999) 67 Antitrust Law Journal 243; contra AH Silberman, 'The Myths of Franchise “Market Power”" (1996) 65 Antitrust Law Journal 181.

93 Queen's City Pizza v Domino's Pizza 124 F3d 430, 438 (3d Cir 1997); Forsyth v Humana 114 F3d 1467, 1476 (9th Cir 1997).

$94 \quad$ See Newcal Industries v Ikon Office Solution 513 F3d 1038, 1048-9 (9th Cir 2008), cert den 129 SCt 2788 (2009); In re Apple \& AT\&TM Antitrust Litigation, 596 F Supp2d 1288, 1302-6 (ND Cal 2008); Datel Holdings v Microsoft, 712 F Supp2d 974, 985-90 (ND Cal, 2010).

$95 \quad$ P Areeda and H Hovenkamp, Antitrust Law, Vol 2B (3rd edn, New York, Aspen 2007) § 519, with 2013 Supplement 205-10.

96 For references, see F Wagner-von Papp, 'Comparative Antitrust Federalism and the ErrorCost Framework' in N Charbit and E Ramundo (eds), William E Kovacic: An Antitrust Tribute - Liber Amicorum Vol II (New York, Institute of Competition Law 2014) 23, 67-8. 


\subsection{2.4 Comparison}

From a bird's eye perspective, the jurisdictions surveyed here show remarkably similar traits. They control unilateral conduct of non-dominant firms. They provide for prohibitions of price discrimination. They prohibit sales below cost. They are concerned about buyer power of large retailers/chain stores and prohibit them from demanding preferential treatment (these latter rules are also remarkably uniformly ineffective). They are concerned about bargaining power imbalances between parties in long-term contractual relationships and ex post opportunism. Political support for these rules seems strong in all jurisdictions, and the justification of the rules is more or less openly the protection of small and medium enterprises ('mom-and-pop' stores). To the extent that there is competition advocacy by authorities for abolishing the rules (RPA in the US, sales below cost in Germany), this advocacy is unable to overcome the political forces. Competition authorities appear to be in two minds about these provisions: on the one hand, they make little to no sense from a competition policy perspective; on the other hand, they make life easy for the authority and can, if responsibly handled, even have some positive effects.

There are differences, to be sure. The most obvious difference is the level of bargaining power that is required for intervention. In Japan no 'market power' is required for the application of the rules on superior bargaining positions; it is the bargaining power inter partes that counts.

In Germany, the self-contradictory term 'relative market power' reflects the ambiguous nature of the level of power that is required: on the one hand, courts primarily look at the switching possibilities for the dependent undertaking - the postcontractual locked-in position. To that extent, German law looks to the inter partes bargaining power, similar to Japanese law. However, authorities and courts also look to the relevant market; to the extent there is sufficient choice on that market, any 'self-inflicted' dependency by the dependent undertaking is said to be disregarded, unless entering into this dependency was also in the interests of the undertaking with relative market power. The uneasy vacillation between bargaining and market power, between choice on the relevant market and restricted choice of the dependent undertaking in the post-contractual locked-in position is concealed by taking a 
'comprehensive view' of all these different factors in the interest-balancing part of the analysis.

My impression is that it may be slightly easier to establish dependency under Japanese law than relative market power under German law. German courts tend to treat dependency as the exception, and require that the allegedly dependent undertaking lack outside options; the assessment roughly follows the pattern of a finding of a dominant position. If the Japanese Guidelines are an accurate reflection of the law in action, and if it is true that affiliate offices may be considered dependent even if they are part of an undertaking that has more power than the undertaking in the allegedly superior position, then it seems easier under Japanese law to invoke the rules on superior bargaining position.

The situation is arguably different when it comes to 'superior' market power under German law - here, the assessment is essentially a mechanistic comparison of the relative 'bigness' of the large undertaking vis-à-vis the SME competitors.

However, some of the Japanese unfair trade practices do not explicitly require any power threshold for their application. Indirectly, a power threshold may play a role to the extent that at least the concrete possibility of effects is an element, as in the example of 'unjust low sales prices'.

Most US rules that were deemed functionally equivalent have no particular power threshold. The first, obvious, exception is the application of section 2 Sherman Act (if one followed the Newcal post-contractual lock-in rationale). The second, possible, exception is RPA claims after Volvo Trucks. Even though the RPA does not itself have a power threshold, and even though a substantial majority of the early RPA enforcement was against SME enterprises rather than against large corporations, ${ }^{97}$ the Supreme Court's 2006 Volvo Trucks decision introduced a slightly vague power requirement: some market power resembling that of chain stores appears to be the standard. In contrast, most of the sales below cost statutes do not have any market or

97 FM Scherer and D Ross, Industrial Market Structure and Economic Performance (3rd edn, Boston MA, Houghton Mifflin 1990) 515-6 (noting that only 6.4 per cent of the 564 companies named in complaints between 1961 and 1974 had sales of $\$ 100$ million or more, and that more than 60 per cent had sales below $\$ 5$ million, adding that the large undertakings were more successful in having complaints dismissed). 
bargaining power threshold. This may be particularly pernicious, because it means that the 'mom-and-pop' stores that these statutes supposedly protect may be prohibited from underselling competing chain stores which can sell at a lower price because of their lower costs (be it owed to buyer power or owed to efficiencies in scale and scope), unless there is a meeting-competition defence or an intent to exclude element.

There are, of course, many other differences. For example, the discussion above has not addressed enforcement issues. In Germany, most of the enforcement under $\S 20$ ARC is private enforcement (although public enforcement with fines is possible and, as the Rossmann case showed in its ugliest form, does occur). In the United States, public RPA enforcement on the federal level has ceased to exist, and RPA enforcement 'has become an activity pursued mainly by private treble damages litigants'. ${ }^{98}$ In Japan, public enforcement of the superior bargaining position provisions by the JFTC has seen an increase since the new surcharge provisions were introduced, and is even one of the JFTC's stated priorities; ${ }^{99}$ Wakui and Cheng consider the public enforcement of these provisions to be essentially a substitute for weak contract law enforcement. ${ }^{100}$

\subsection{SHOULD UNILATERAL CONDUCT BY NON-DOMINANT FIRMS BE SUBJECT TO COMPETITION LAW?}

\subsubsection{Error Costs Compared}

98 Ibid, (although DD Sokol, 'Analyzing Robinson-Patman' (2015) 83 George Washington Law Review 2064, 2079 in fn 137, notes that RPA class actions are not certified, making the area not a very lucrative one for the plaintiff bar; nevertheless, private secondary-line enforcement remains viable, see Sokol's data reported supra $\mathrm{n} 74)$.

99 S Takizawa and K Arai, 'Abuse of Superior Bargaining Position: The Japanese Experience' (2014) 5 Journal of European Competition Law and Practice 557.

100 M Wakui and TK Cheng, 'Regulating Abuse of Superior Bargaining Position under the Japanese Competition Law: An Anomaly or a Necessity?' (2015) 3 Journal of Antitrust Enforcement 302. 
Subjecting unilateral conduct to competition law scrutiny is always costly, because procompetitive conduct may falsely be categorized as anticompetitive (false positive), or because the uncertainty about the standard may chill conduct that would have been procompetitive. Prohibiting or chilling procompetitive conduct leads to competitive harm: the intensity of competition is reduced where otherwise available options are eliminated. This is true not only where competitors eliminate these options, but also where competition law enforcement eliminates them. In the latter case, the elimination is even more powerful because it is legally enforceable so that the market's self-correcting tendency is eliminated as well. Overzealous competition law enforcement can become counterproductive.

This is a commonplace even in the case of competition law scrutiny of unilateral conduct of dominant firms. In the case of dominant firms, however, there would also be a high cost to refraining from scrutinizing unilateral conduct. While we want the dominant firm to compete vigorously, we want to avoid exclusionary (and/or, depending on the jurisdiction, exploitative) conduct. The scrutiny of unilateral action is always torn between the Scylla of false positives, in which case procompetitive conduct is prohibited or chilled, and the Charybdis of false negatives, in which case competitors may be excluded and competition restricted.

In the case of non-dominant firms, however, it is very unclear at best what the competitive harm of inaction would be. There are clear downsides but no upsides.

\subsubsection{Sales below cost}

This is most clearly the case where prohibitions of sales below costs are concerned. Even in the case of predatory pricing by a dominant firm it is sometimes argued that while consumers benefit from the low prices during the predation period, it is far from certain that the scheme will ultimately be successful, so that it may never come to the recoupment stage or to consumer harm. ${ }^{101}$ However, in dominance cases there is at

\footnotetext{
101 This is the combined argument from Matsushita: '[T]here is a consensus among commentators that predatory pricing schemes are rarely tried, and even more rarely successful' and 'cutting prices in order to increase business often is the very essence of competition. Thus, mistaken inferences in cases such as this one are especially costly, because they chill the very conduct the
} 
least a plausible theory of harm: if the dominant firm's scheme does succeed, competitors would be excluded (or disciplined), competition would suffer in the recoupment phase, and consumers would ultimately be harmed. Competition law regimes try to balance the pros and cons carefully in these predatory pricing cases. The balance of the type I/type II error calculation changes dramatically where sales below costs of non-dominant firms are concerned. First, the lower the threshold of market power, the higher the number of addressees, and the higher the costs of false positives: while a prohibition of predatory prices for dominant firms may chill some procompetitive price reductions by firms close to the dominance-threshold or close to the cost-threshold, a prohibition of sales below cost for firms with merely superior bargaining power will catch many more firms (in particular many supermarkets), and a prohibition of sales below costs without any market share threshold will affect the conduct by every market participant: low pricing will be chilled to the detriment of the consumer. Second, the theory of harm becomes speculative at best. Most cases of sales below cost concern a loss leader - customers are meant to be attracted to a store and do their one-stop shopping there. Overall, the store's costs are covered because the losses from the loss leader are (more than) compensated by profits from the sale of other products.

Despite the superficial similarity between predatory pricing by dominant firms and sales below costs by firms below the dominance threshold, the quasi-predatorypricing narrative of harm is therefore not persuasive. Accordingly, alternative justifications have been advanced to justify prohibitions of sales below cost.

One of these alternative justifications is that sales below cost statutes are said to protect suppliers of typical loss leaders such as milk and milk products, such as dairies and farmers. Again, however, the argument is unpersuasive: if 'powerful' supermarkets are not allowed to sell below cost, but want to offer milk cheaply to attract customers, they have to depress their costs - in other words, they have to exert monopsony power to drive prices down. Sales below cost statutes do not help, but, if anything, hurt suppliers.

antitrust laws are designed to protect.' Matsushita Electrical Industries Co v Zenith Radio 475 US 574, 589, 594 (1986). 
Yet another alternative theory of harm is the consumer protection narrative: precisely because loss leaders entice customers into the store to buy other products as well, they are said to be 'deceptive'. However, few consumers would think that because milk is cheap in a store that therefore all other goods in that store have to be cheap as well. It may well be that consumers buy more than the milk products which they wanted to buy when initially entering the shop. It may also be true that this is owed to information asymmetry (where the consumer does not know the competitors' prices for these additional products) or to bounded rationality, for example bounded willpower (where the consumer knows that competitors offer the product more cheaply, but succumbs to the lure of instant gratification). Whatever label we attach to the lure of low milk prices, however, it is merely a marketing device as any other. It is simply not enough to attach the label of market failure in order to get to a credible theory of harm. Accordingly, the 'deception' narrative does not persuade either. Instead, sales below cost statutes are a form of redistribution of money from consumers to sellers. It is a legislatively mandated form of restricted price competition. It should be noted that it is not necessarily SMEs that benefit. Because the large retailers usually have lower costs - because of efficiencies of scale and possibly monopsony power -, it will usually be enough for the large retailers to sell at cost to undercut the 'mom and pop' stores. Where the prohibition of sales below cost applies even to the 'mom-and-pop' stores (which is true in some US states, but generally not in Germany or Japan, where at least superior market power is necessary), the 'mom-and-pop' stores are additionally deprived of the possibility to compete at least by selling below their own cost. To the extent this is the case, the prohibition of sales below cost may even hurt rather than protect SMEs.

\subsubsection{Freedom of contract and Coase theorem}

While the substantial costs and lack of redeeming benefits are particularly clear in the example of sales below cost, similar considerations apply in all the cases of scrutiny of unilateral conduct of non-dominant firms. Ex post control of the content of negotiated contracts impinges on the freedom of contract. Where transaction costs are sufficiently low, negotiations result in the efficient allocation of resources (Coase). 
Where the freedom to negotiate is restricted, the parties have an incentive to circumvent the restriction.

If, for example, retroactive discounts for large buyers are prohibited, there is an obvious incentive for the parties to contract for short-term contracts. Where the protection of the dependent supplier or distributor becomes too onerous for the firm in a 'superior' position, it may choose vertical integration even in circumstances where, in the absence of the interference from competition law, vertical integration would have been considered inefficient.

\subsubsection{Protection of the Weaker Party, Outside Options and Proper Market Definition}

The protection of the weaker party may seem a worthy goal. Nevertheless, it is surprising that competition legislators and authorities go to great lengths to interfere with the adequacy of consideration where firms in a superior bargaining position are concerned. Even in consumer law, there is no equivalent tendency to interfere directly with the terms of the contract to the same extent, even where there is an 'imbalance in bargaining power'. The reason why the legislator goes along is arguably to be found in public choice reasons: SMEs often have a powerful lobby, and SME arguments additionally sound good to voters, who may not realize that the protection is financed out of their pockets.

The reason why competition authorities often play along is, as Professor Shiraishi has put it: 'they can enjoy a loose requirement for prosecuting illegal conduct. They also tend to focus on protecting small- and medium-sized enterprises (SMEs) under political pressure. ${ }^{, 102}$

The question really is under what conditions one party is 'weaker' than the other. It would be a mistake to assume that just because one firm is large and the other is small the former need necessarily be more powerful. Whether a firm has a strong or a weak bargaining position does not depend on its size, but on its outside options. Where

102 T Shiraishi, 'A Baseline for Analyzing Exploitative Abuse of a Dominant/Superior Position' (2013) 5 UT Soft Law Review 1, 3, available at <http://ssrn.com/abstract=2246558> (last accessed 20 August 2018). 
there is effective competition in the market, even a single consumer may have equal bargaining power to a large retailer. Only where there is no effective competition is there a disparity of 'bargaining power'. Whether or not there is effective competition is determined by the presence or absence of a (single or collective) dominant position in that market. Where there is effective competition, the 'smaller' party has sufficient outside options and is therefore not dependent on the other party.

Conceptually, then, dominance is a necessary condition. Whether dominance exists depends on the area of effective competition - in other words, market definition.

As mentioned in the introduction, Professor Shiraishi has argued that in superior bargaining position cases, the market may often have to be defined very narrowly, justifying the result even as an abuse of a dominant position. ${ }^{103}$

He exemplifies this with two examples: the $S M B C$ case and the Seven Eleven case. In the $S M B C$ case, a bank had tied interest rate swaps to loans for SMEs. The SMEs were said to have had no outside options for loans. From this, the JFTC deduced the bank's superior bargaining position; Professor Shiraishi deduces from the same facts that 'the relevant counterparts were specific SMEs distinguishable from general SMEs, and the relevant market was not the whole loan market, but the loan market for those SMEs captured by SMBC'. ${ }^{104}$

Similarly, in the Seven Eleven case, a franchisor had imposed an onerous requirement on its franchisees. The franchisees were subject to a one-year post-contractual noncompete obligation and were therefore considered to be dependent by the JFTC. Professor Shiraishi considers that ' $[\mathrm{t}]$ he relevant trading counterparts were SevenEleven franchisees, and distinguishable from general convenience store franchisees'. 105

The starting point of this analysis is sound: if we want to identify a competition law problem, we must look for dominance. And in principle, it is possible to find dominance if a market is narrowly defined. And in some circumstances, a lock-in argument may lead to a narrow market definition.

\begin{tabular}{ll}
\hline 103 & Ibid. \\
104 & Ibid, 5. \\
105 & Ibid.
\end{tabular}


However, the label 'lock-in' should not become a substitute for a proper market definition. As explained above, the difference between 'market dominance' and a 'superior position' is important in those cases in which there is generally effective competition on the market, but some market participants are locked in, for example due to transaction-specific investments.

Simply focussing on the customers who are locked in and defining the market accordingly would be akin to the 'toothless fallacy' in United Brands, which focussed on the 'the very young, the old and the sick', who could only eat bananas and could not switch to other fruit, to hold that the relevant market was the market for bananas; ${ }^{106}$ or akin to the simplistic approach to aftermarkets without considering the possibility of systems competition. ${ }^{107}$

The question has to be whether the market for Seven Eleven franchisees or the market for loans for the locked-in SMEs in SMBC was worth monopolizing. Would it have been profitable to raise prices on the so-defined narrow market? First, there is the question if arbitrage would be feasible - if these SMEs could not get loans from other banks, and the bank raised its prices for loans for the locked-in SMEs, would it be possible for an arbitrageur to get a loan elsewhere and offer a new outside option to the (in that case only apparently locked-in) SMEs? Second, and perhaps more importantly, what would the reputational effects be? If the general market for loans is competitive, and new customers can observe that the bank opportunistically takes advantage of locked-in customers, the opportunistic behaviour may not be a profitable venture - provided the proportion of new customers being deterred from entering into a relationship with the bank is sufficiently large.

\subsubsection{Summary}

\footnotetext{
106 Case 27/76 United Brands v Commission [1978] ECLI:EU:C:1978:22 [29]-[31] .

107 H Hovenkamp, 'Market Power in Aftermarkets: Antitrust Policy and the Kodak Case' (1993) 40 UCLA Law Review 1447; see also Directorate General (DG) Competition 'Discussion Paper on the Application of Article 82 of the Treaty to Exclusionary Abuses' (December 2005) Section 10, available at <http://ec.europa.eu/competition/antitrust/art82/discpaper2005.pdf> (last accessed 20 August 2018); for an excellent discussion in German see S Bechtold, Die Kontrolle von Sekundärmärkten (BadenBaden, Nomos 2007).
} 
(1) Only in cases where a market is dominated, so that there is no effective competition providing sufficient outside options for the 'weaker' party, is there a credible theory of harm that can justify the (administrative and type I error) costs associated with the control of unilateral conduct.

(2) A finding of 'superior bargaining power' is usually based on factors that constitute or imply a 'lock-in', reducing the price elasticity of demand for the locked-in group. These considerations may justify defining the relevant market more narrowly.

(3) However, a lock-in does not automatically justify defining the market narrowly so as to comprise only the locked-in consumers. In particular, it is possible that consumers that are not, or not yet, locked in and therefore have a high price elasticity of demand make raising prices on the market for locked-in consumers unprofitable. Whether this is the case will depend, among other things, on the proportion of locked in to 'free' consumers, and on how transparent the conditions imposed on the locked-in consumers are.

\subsubsection{Proof of Dominance and Superior Bargaining Positions}

Watering down the threshold from market dominance to an ill-defined 'superior position' or 'relative/superior market power' standard is intellectually lazy. However, abolishing these lower thresholds and relying exclusively on a finding of dominance may present practical problems. In particular, even in cases in which there actually is market dominance and where a credible theory of harm can therefore be advanced, it may not always be possible for the plaintiff or authority to prove dominance. This could lead to type II error costs, which may be substantial. One of the reasons why the concept of relative market power was introduced in Germany was precisely to enable private enforcement: while private plaintiffs are able to demonstrate why they are dependent on an undertaking with relative market power, they will often lack the information necessary to prove dominance on the relevant market, in particular in light of the traditionally weak disclosure regime in German procedural law.

If this, however, is the motivation for retaining the lower thresholds, then they should be reduced to mere prima facie indicia or presumptions. If the intention is to allow 
enforcement only in cases of actual dominance, then it should always be open to the 'relatively powerful' firm to prove that it is not dominant. 